\title{
2. Performing law: The Yolngu of Blue Mud Bay meet the native title process
}

\section{Frances Morphy}

\author{
This land was never given up \\ This land was never bought and sold \\ The planting of the Union Jack \\ Never changed our law at all \\ Treaty (1991) Mandawuy Yunupingu with Paul Kelly and Peter Garrett
}

\section{Introduction}

The native title process is an arena in which, among other things, the sovereignty of a colonising society over its colonised subjects is enacted. As Julie Lahn (Chapter 7) points out, native title is based on a 'radical assumption of sovereignty' and the legislation and the growing body of native title case law 'can be said to continue to exercise the power that defines sovereignty...[a]nd in this sense, it is certainly possible to contend that native title is as implicated in ongoing processes of colonisation, as providing a remedy to aspects of it'.

The Yolngu response to the native title process in the Blue Mud Bay case was in continuity with a long-term tradition of political interaction with the colonising society and its institutions. ${ }^{1}$ It is a response that declares, in essence, 'we know we are encapsulated, but we are not colonised'. Yolngu have never fully acceded to the proposition that their sovereignty has been eclipsed by the process of colonisation. When sovereignty was asserted over their region by the colonial power - in abstract and at a distance - their ancestors knew nothing of it. Although the colonial frontier encroached upon the fringes of their region many years later, in the early years of the 20th century, there was no significant permanent Euro-Australian presence in the Yolngu heartlands until the establishment of the first missions in the 1930s. At the time Yolngu did not perceive the coming of the missionaries as an act of colonisation nor did they view their own response as a ceding of sovereignty. Nancy Williams writes that: 'From a Yolngu perspective it was Mawalan, as head of the land-owning Rirratjingu clan, who granted permission to Chaseling, as agent of the "mission" to establish the station at Yirrkala [in 1935]' (Williams 1987: 20).

\footnotetext{
1 The initial determination of the Blue Mud Bay case can be found at Gawirrin Gumana v Northern Territory of Australia (No. 2) [2005] FCA 1425. The determination of the Full Federal Court hearing may be found at Gumana v Northern Territory of Australia [2007] FCAFC 23. Links to the two determinations may be found on the website of the National Native Title tribunal at <http://www.nntt.gov.au/ntdetermination/1136779170_3832.html> (accessed 4 September 2007).
} 
Yolngu were brought face to face with colonial power in the 1960s in what became known popularly as the Gove Land Rights case, when the clans of the Yirrkala area took the bauxite mining company Nabalco and the Commonwealth of Australia to court over mineral leases that had been granted to the mining company by the government. ${ }^{2}$ The Yolngu view of the encounter and its aftermath is that although they lost that battle they won a longer war, in that the Aboriginal Land Rights Act (Northern Territory) 1976 (ALRA), which granted the Traditional Owners rights in fee simple over the rest of the Yolngu clan estates (to the low water mark), is seen as a direct result of that earlier loss.

Manuhia Barcham, in his presentation to the workshop Effects of native title from which the present volume originated, drew attention to the 'politicised nature of the [native title] recognition space'. The politicisation of the space can come from more than one direction. Today's Yolngu are not naïve, nor are they in a state of false consciousness about the nature of the political situation in which they find themselves. They see and understand the power relations that allow the Australian state to assert its sovereignty over them. But they also consider that this sovereignty was imposed without their consent, and that there never was an act of conquest. They see the ALRA as an acknowledgement of that fact by the state, and to that extent they question the legitimacy of the state's assertion of sovereignty over their estates. In their view the native title process was as much about the issue of sovereignty - at least in the sense of the recognition of the jurisdiction of Yolngu 'law' — as about 'rights', and their participation in the process must partly be understood as a political act.

This much was clear in discussions with their representing barrister during preparations for the case. The view they put to him rhetorically was, in paraphrase: 'We know that we own our sea country under our law. Why is it not sufficient for us simply to state this to the court? Why do we have to prove our law under ngapaki [white] law ${ }^{3}$ The barrister's response was, in effect, that as citizens of Australia they were subject to what they were calling ngapaki law, that ngapaki law was not just for ngapaki but for all Australians. He acknowledged that this situation had come about through a prior act of colonisation, but, to paraphrase again, 'that's just the way it is, and that's what we have to work with'.

For the late Mr Justice Selway, who heard the Blue Mud Bay native title case, sovereignty was naturally not at issue. The very existence of the Federal Court, and of the Native Title Act presupposes the sovereignty of the state, and, moreover, '[f]ollowing Mabo (No 2) the High Court rejected attempts to use native title as a vehicle to claim indigenous legal and political sovereignty'

${ }^{2}$ For a detailed account of this case (Milirrpum vs Nabalco and the Commonwealth of Australia) and the Yolngu response see Williams (1986).

3 David Claudie (Chapter 5, see p. 89, 101 and fn. 15) takes a similar view. 
(Mantziaris \& Martin 2000: 28). But the judge did recognise explicitly that the applicants considered this case as: 'merely the latest aspect of a more protracted campaign. For my part it is difficult to imagine what more the Yolngu people, including the claim groups, could or should have done lawfully to enforce their rights' (Selway J 2005 [ 213]).

From the anthropologist's point of view then, the Blue Mud Bay hearing can be seen as Yolngu discourse about the sovereignty of rom (Yolngu 'laws and customs') embedded in a native title discourse about rights under European law. In analysing this discourse within a discourse, the paper looks first at the constraints created by the form and structure of the court, and then at the strategies Yolngu applied to insert their discourse about sovereignty. Their political agenda was rarely explicitly stated, but rather manifested in the strategies that they adopted in their responses to questioning and in their deliberate placement, at two carefully selected points in the proceedings, of performances of rom. The paper concludes with some thoughts about the more long-term effects of the case on the Yolngu view of their position as encapsulated but not colonised subjects.

\section{A brief ethnography of the court: performance and enactment}

The term 'arena' in the opening sentence to this paper is used quite deliberately. A native title court is an arena for the enactment of law-European law. Rom is present, and it may under certain circumstances be performed, but it is not enacted in the sense of having any legal force in this arena. This distinction between performance and enactment is central to the analysis presented here, for sovereignty is asserted through enactment. In the court, European law is sovereign in that it is simultaneously performed and enacted - or is enacted through its performance, whereas rom is the object of discourse; it is explicated through the mediating discourse of examination and cross-examination. If performances of rom are inserted into the proceedings, these do not count-from the court's point of view - as enactments of rom. They do not even count as evidence about rom, unless they are also explicated in oral or written evidence. ${ }^{4}$

But from the Yolngu point of view (for reasons that will be elaborated later), any performance of rom, in whatever context, simultaneously constitutes an enactment of rom, and performance in the context of the court it is therefore, among other things an enactment that demonstrates the sovereignty of rom.

4 Sturt Glacken (pers. comm. 9 November 2005) notes that there is legal provision for evidence by performance. 'If it is used', Glacken notes, 'there would then need to follow conventional evidence explaining its symbols'. In this case, bark paintings made by the claimants that depicted their land and sea country were used as evidence in precisely this way. 


\section{The arena}

The forms and rituals of the court come as second nature to those who are expert practitioners, but they are as exotic and potentially impenetrable to Yolngu claimants in a native title case as Yolngu ritual forms are to non-Yolngu.

The performance space - the courtroom - is a constructed ritual space. This much was obvious to Yolngu because the court was held in a building at Yirrkala to which everyone normally has access - the adult education centre. Fig. 2.1 shows how the main teaching/meeting room became a courtroom. The space was transformed symbolically by the placing of the symbol of the court - the Australian coat of arms bearing the figure of the kangaroo and the emu - at the front of the room, and then this symbolic space was divided into clear zones. ${ }^{5}$ In front of the kangaroo and emu stood a table - the 'bench' - at which sat the judge and his associate. The court recorders sat to one side and the witness and the interpreter sat opposite them, to the other side of the judge.

\section{Fig. 2.1 The ritual space of the court}

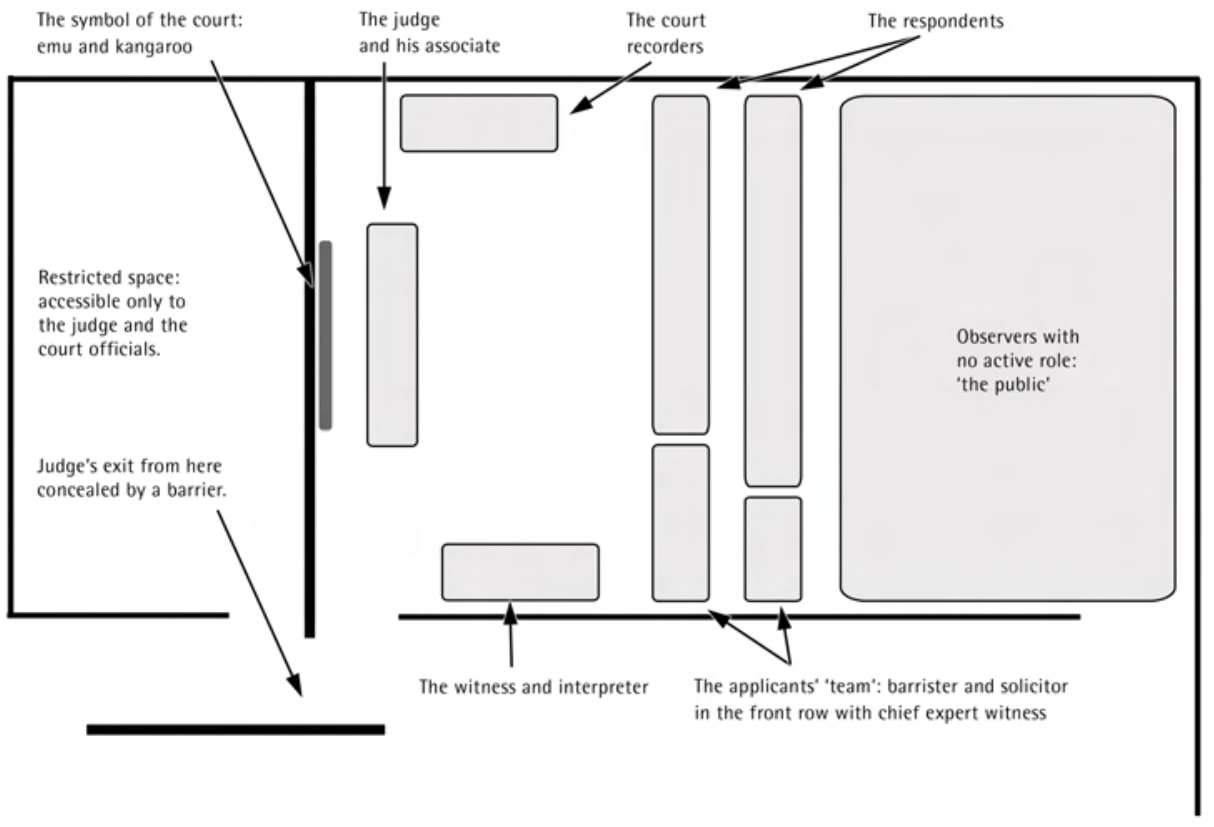

The space between these two flanking tables was empty. Facing the judge across this space were two lines of tables and chairs. The first row was occupied by the teams for the applicants and the most active respondents (the Northern

5 Ironically, the emu is one of the main ancestral beings for one of the Yirritja moiety clans involved in the case, and the wallaby has the same status for one of the Dhuwa moiety clans involved. 
Territory and Commonwealth governments), including the expert witnesses, and the second by the less active respondents and me (an expert witness with a non-speaking part). This completed the arena in which action took place. In the back half of the room, again separated by an empty space from the actors in the proceedings, was the space for the 'public' to sit.

Adjoining the public court there was a restricted space to which only the judge and the court officials had access. ${ }^{6}$ The entry of the judge from the restricted space into the public space took place through a door at the front of the court. Everyone else entered through the door at the rear of the court. ${ }^{7}$

\section{Who gets to speak, and how}

The Australian court system has an elaborate set of rules for proper discourse, in which different actors have different roles according to their status and function. Certain categories of persons can speak publicly; others - solicitors and expert witnesses who are not on the stand - can give written advice to their colleagues with speaking parts, but may not themselves speak. The discourse rules are well understood and are manipulated (with varying degrees of subtlety) by the actors in the court who have legal training, but they are not transparent to, nor are they explicitly laid out for, the 'lay' actors - the witnesses - who must attempt to learn the rules as they go along. The system is also hierarchical, and that hierarchy is made manifest in the degree of constraint to which different actors must submit themselves. At the top of the hierarchy is the judge, who is the least constrained. It would appear that he or she can speak at any time, freely interrupting the speech of others.

The hierarchy of constraints is ostensibly designed to control the flow of information into the official record of the court, in such a way as to maximise the production of objective 'facts' that are relevant in law to the particular case, according to a particular set of 'rules of evidence'. It is a highly positivist enterprise. In native title cases it has a paradoxical effect, when viewed from the perspective of the applicants - the purported 'native title holders'. They, who are the most knowledgeable about their own system of 'laws and customs', have the most severely curtailed rights to speak in the body of the court. They may only speak when spoken to. Their barrister, who has spent time with them preparing the case and is likely to have more knowledge of their 'laws and customs' than any of the other counsel present, is bound by the rules of evidence to act 'as if' he knew nothing, because he may not ask leading questions - that

6 Yolngu witnesses saw a parallelism between the public and restricted spaces of the court and the public and restricted grounds of Yolngu ceremonial performance. That only the judge (and his court officials) had access to the restricted space was seen (correctly) as an indication of his pre-eminent status in the proceedings.

7 An exception was made for the witnesses and interpreters when it was realised that entry through the back door was impossible once all the barristers and others were seated. 
is, he may not ask questions that contain knowledge that he and the applicants know that they all hold in common. ${ }^{8}$

Prior to the court hearing, a set of detailed witness statements had been prepared. The witnesses had understood that these were to form the basis of questioning that they would be facing in the court hearing. There had been some discussion at the directions hearings preceding the court hearing about how these statements were to be used. The respondents had wanted full statements in writing, and to have the portions to which they raised no objections accepted as the witnesses' evidence in chief. In the case of objections, the relevant paragraphs were to be lead orally from the witnesses. Counsel for the applicants had objected to this process. He favoured providing summaries of the evidence and otherwise leading evidence orally. The judge noted his objection to the process advocated by the respondents.

The judge was concerned to make the proceedings as short as possible. Accordingly, at the beginning of the court proceedings large portions of the witness statements were indeed accepted into evidence, with no objection from the respondents. But there remained certain paragraphs or sentences that the respondents did not allow into evidence, and insisted should be the subject of oral examination in the court. Although the counsel for the applicants was not explicitly confined to leading only the evidence in these excised portions of the witness statements, in practice the timetable set by the judge made it impracticable to do anything else. ${ }^{9}$ As a result, the witnesses found themselves being asked a very narrow range of questions. ${ }^{10}$ Towards the end, the last witness $(\mathrm{X})$ obliquely voiced his frustration with this state of affairs:

Counsel for the applicants (CA): Now, I'll move on to [paragraph] 66 [of $\mathrm{X}^{\prime} \mathrm{s}$ witness statement]. Just - this deals with, $\mathrm{X}$, this deals with the idea of catching a turtle or a big animal on a person's country. Can you tell us what happens when if you catch a turtle or a big animal on somebody else's country?

\footnotetext{
8 This was not true in the original version of the Native Title Act, which was similar to the ALRA in terms of its attitude to evidence. The Act was amended in 1998, so that 'normal' rules of evidence now apply. The Blue Mud Bay case was run under both Acts, but before a Federal Court Judge rather than in a Land Rights Commissioner. Thus Federal Court rules of evidence prevailed.

9 I am grateful to Tom Keely (pers. comm. 3 April 2007) for explaining the finer points of the leading of the evidence to me. Any remaining errors of fact and interpretation are mine.

10 In the week immediately prior to the hearing, the young adult daughter of one of the main appellant witnesses died suddenly and unexpectedly. During the period of the hearing, her body was in Darwin for the coroner's inquest into the cause of death. One of the issues that the respondents' barristers wished evidence to be led on was the question of the closure of areas of the sea and shore following a death. So a side-effect of the strategy adopted by the court was that the witnesses (apart from the father), several of whom were also closely related to the young woman, were subjected to lengthy questioning on the topic of death and its consequences. While people found this emotionally difficult, they nevertheless saw that it strengthened their evidence to be able to show how they were acting in relation to this death.
} 
X: Yes, I think we are all aware about that. We had three - six people sitting down here telling the same stories. Now I'm going to do the same thing and tell the same stories. When we get turtle from - from another country... ${ }^{11}$

The counsel acting for the respondents are free to ask leading questions if they so wish, and are not confined to leading evidence from the witness statements. They may even, as a tactic, pose questions that are deliberately founded on ignorance or wilful misunderstanding of the facts. The latter were sometimes deliberately deployed to attempt to confuse the witness, or to lead them towards a conclusion that they would not freely subscribe to.

From the point of view of the non-initiate - Indigenous or non-Indigenous - the structure of the discourse imposed by the court seemed designed, whether intentionally or not, to emphasise the power of the European law by systematically constraining the ability of the knowledgeable practitioners of rom to express rom clearly in its own terms and in its fullness.

This was a paradoxical effect, because the judge's intention had been quite different. He was proceeding from the premise that he only needed to know from the witnesses that which was relevant to native title law-it was not his role, as he said, to become an anthropologist or an expert in Yolngu law. He was also clearly concerned to minimise the adversarial aspects of the judiciary process on the witnesses: he enjoined the respondents not to attack their credit, and he clearly wished to set limits on the number of witnesses, and on the length of their appearances on the stand, not simply to expedite the hearing and confine proceedings to what he saw as the relevant facts, but also to minimise the potential for adverse impacts on the Yolngu claimants.

To some extent, then, the judge and the claimants were at cross purposes. While the judge was concerned to minimise the impact of the proceedings on the claimants, the claimants were concerned to produce as much of an impact on the court as they could. They saw the court as a platform for demonstrating the power of rom and the depth of their knowledge about it - as a site for persuasion. ${ }^{12}$ This is in continuity with earlier Yolngu views of the court in the Gove case, as described by Nancy Williams:

The Yolngu leaders perceived the court less in adversary terms than as a setting where their role was to assist the court to learn about their ownership of land, They saw an opportunity 'to explain', and explanation in their terms involved 'to demonstrate' ... For the Yolngu the situation was marked by explanation that would result in understanding. They found it difficult to accommodate defence counsel's mode of questioning, and of

11 Court transcript (henceforth T) 815.26-35.

12 On Yolngu and the concept of persuasion, see also Morphy (1983). 
attempting to elicit from them inconsistent or contradictory responses ... the Yolngu leaders were unprepared for a situation in which Europeans explain only enough to 'win' (1986: 159; emphasis added).

During the proofing stage of the Gove land rights case W. E. H. Stanner and the claimants' solicitor Frank Purcell were taken to a place where they were shown sacred objects. Stanner recalled: 'One of the men said to me: "Now you understand". He meant that I had seen the holy rangga which in a sense is the clan's title deeds to its land, and heard what they stood for: so I could not but "understand"'(1979: 278).

In the Blue Mud Bay case, the claimants were more conversant with the conventions of court hearings than their forebears had been, having had more direct or indirect experience of the adversarial system in the intervening years. However the connections between explanation, demonstration and understanding, as detailed by Williams and Stanner, hold equally strongly for Yolngu today.

\section{The witness statement-neither fish nor fowl?}

From a sociolinguistic point of view, the 'witness statement' is an interesting and problematic document. The judge in this case considered it to be a valuable tool. In his judgment (Selway J 2005) he said in part:

$182 \ldots$ in many cases it is convenient to have evidence in chief given wholly or largely by means of a prepared statement. This not only reduces the time involved in the hearing - it also assists in ensuring that the applicant's case is prepared well in advance of trial and that the respondent(s) is not taken by surprise ...

183 I accept that this may need to be qualified in relation to some witnesses who may be disadvantaged by this course, which may include some Aboriginal witnesses ... However, I do not think that those disadvantages arose in this case. The Yolngu witnesses were all obviously intelligent. Most of them seemed relatively sophisticated as to the ways of European society ... All the witnesses were senior law men in relation to a legal system of considerable complexity. These are not simple and naïve people. Subject to potential issues arising from translation between Yolngu language and English I do not think that the Yolngu witnesses were disadvantaged by the procedure adopted (emphasis added).

I would not quarrel with his Honour's concluding sentence, in this particular case. However, I want to pick up on the phrase that has been italicised. For the process involved in the construction of a witness statement is much more complex than this, and it is not, strictly speaking, translation (Fig. 2.2). 
If it were possible to translate word for word between Yolngu-matha and English, and if we were only dealing with 'layman's' English, then maybe the process would be straightforward. Once the lawyers had written up the statements in English, it would simply be a matter of reading the statement back to the witness (or translating it word for word into Yolngu-matha and reading it back), or getting the witness to read the statement over for themselves. The Yolngu witness might find the formal style of the statement unfamiliar, but that would not be a barrier to comprehension. However, neither of these 'ifs' hold.

\section{Fig. 2.2 The 'translation' steps in a witness statement}

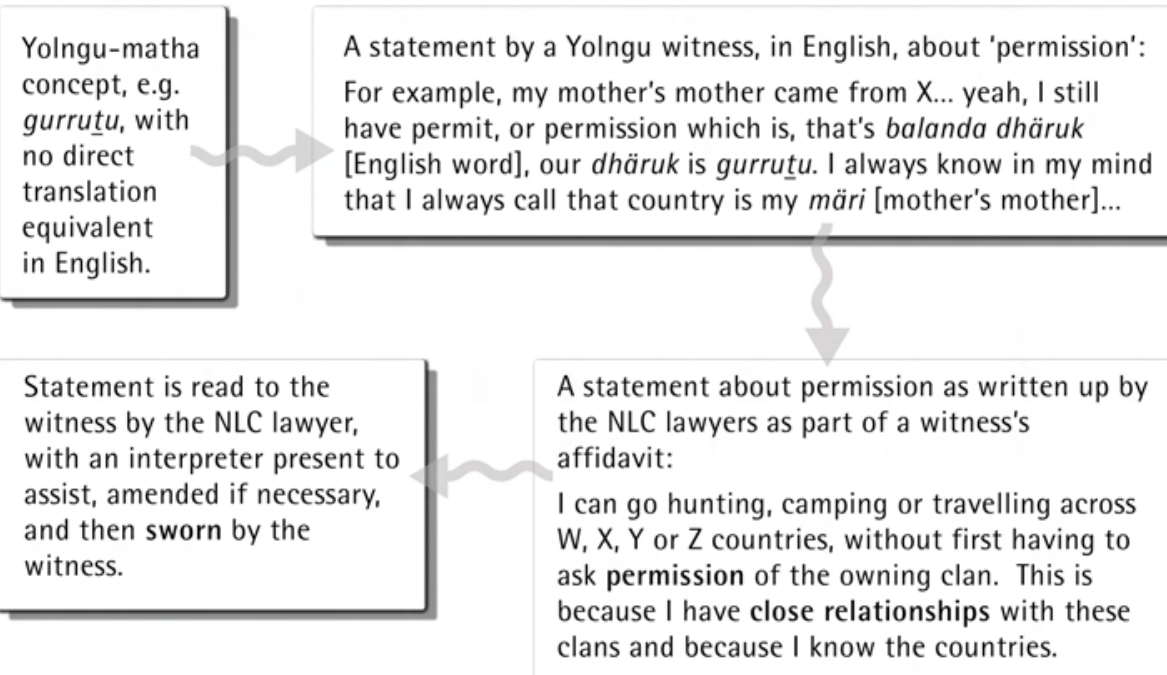

Firstly, there are very few words that can be translated literally from one language to the other. There is, for example, no English equivalent of the word gurrutu, and no Yolngu-matha equivalent of the English word 'permission'. For an English speaker to understand what gurrutu means, it is necessary for them to be familiar with the operation of the Yolngu kinship system, and for a Yolngu person to understand what 'permission' means (in the context of native title) it is necessary for them to be familiar with Anglo-Australian notions of property.

Secondly, and this is something the Yolngu witnesses are not privy to, many of the words that appear in witness statements - words like 'permission', 'speak for', 'resource', 'sing for' and 'connection' - have come to have particular meanings for lawyers who work in native title. Some are defined in the Native Title Act 1993 itself, which gives them status as legalese; others are quasi-legalese - terms that have commonly been used by lawyers in native title cases, and which are in the process of definition as legal terms, with very 
particular meanings. The trouble is that they sound like ordinary English words. So a phrase like 'without first having to ask permission' could conceivably mean something very different to the Yolngu witness to whom it is read from what it means to the lawyer who reads it to him - even if that witness has reflected at length on what 'permission' might be equivalent to in the Yolngu system (as at least one witness had done). To a Yolngu who has not reflected on the meaning of the word, the phrase is, quite possibly, meaningless. ${ }^{13}$

With a moment's reflection, it is possible to see that the 'translation' of a witness statement 'back' into Yolngu-matha so that it can be verified as his own by a Yolngu witness with poor English, is a near impossible task, and one that would be extremely time consuming. For such a document is a hybrid. ${ }^{14}$ It purports to be the statement by the witness about 'laws and customs' (rom), but it is to some degree actually a lawyer's statement about native title. It belongs fully to neither of its authors, and its meaning is inherently indeterminate.

The witness statement is a particular instance of what Mantziaris and Martin have in mind when they write: that 'native title involves a process of translation from indigenous "relations" defined by traditional law and custom to native title rights and interests enforceable within the Australian legal system. This process of translation becomes difficult, or impossible, when the terms of the translation are incommensurable' (2000: 29). I do not take the strong position that incommensurability is inevitable and always uncircumventable. However, I do take the witness statement to be an instance of 'enforced commensurability' in the context of an unequal power relation.

These statements are long documents. The one being discussed in the extract below from the court record is 89 paragraphs long. This in itself makes it unlikely that the witness has a full recall of its contents. Does this matter? Yes, because these documents are treated, according to an unstated convention 'as if' they were the actual words of the witness, when everyone in the court knows they are not. Hence the programmatic nature of their adoption into evidence, where much less attention is paid to the witness's response that the statement is 'true and correct' - this is a formulaic ritual exchange - than to its status as a legal document: which 'matter' it relates to, and which bits have not been accepted 'by consent' into the evidence before the court:

\footnotetext{
13 The noun 'permit' is certainly in the everyday lexicon of most Yolngu people because of the permit system that applies on ALRA land in the Northern Territory. However, its meaning has been extended in Yolngu contexts in a way that makes the Yolngu lexical item 'permit' different from the Standard Australian English lexical item. For example it is possible for a Yolngu to say 'he is my permit for this country', referring to the gurrutu relationship with another person that gives the individual 'standing permission' to access the resources of their relative's country.

14 By this I mean hybrid in the third sense listed by the Macquarie Dictionary: 'anything derived from heterogeneous sources, or composed of elements of different or incongruous kind'.
} 
Counsel for the Applicants (CA): Your Honour, there are two affidavits and also a supplementary witness statement in respect of $\mathrm{X}$.

His Honour $(\mathrm{HH})$ : Yes.

CA: I wonder if X can first be shown the affidavit filed 18 June 2004.

$\mathrm{HH}$ : This is the affidavit in the - -

BA: Judiciary Act matter, yes, your Honour.

HH: Judiciary Act matter, yes

CA: X, would you just have a look at that affidavit there, please? Do you remember some time in June swearing that affidavit? You might like to have a look at it, just to make sure you know what it is. I'm not asking you to read it all, unless you need to do that.

$\mathrm{X}: \mathrm{Mm}$.

CA: All I'm wanting to know at the moment is, is that your affidavit that you made in - - -

$\mathrm{X}$ : Yes.

BA: - - June of this year? And what do you say as to the - whether the - what's in that affidavit, is it true and correct?

$\mathrm{X}$ : True and correct.

CA: Well, your Honour, I tender the affidavit as follows: excluding paragraphs 14, 18, 20,36, 40, 50 the eighth and ninth sentences - - -

HH: Just - eighth and ninth sentence of 50 ?

BA: They're to be excluded. Paragraph 66 the last two sentences, paragraph 71 the last sentence, 73 the last sentence, $74,87,88$, and 89 . I tender the balance of the affidavit, your Honour. ${ }^{15}$

The trouble is that the respondents can, as a tactical manoeuvre, when it suits them, violate the unspoken convention. They can do this because it has no official status in the court. They can question the witness minutely about the precise meaning of a word that 'they' have used in 'paragraph $\mathrm{n}$ ' of their statement. In his determination Justice Selway (2005) drew attention to the one instance of this tactic that came to his notice where, in his opinion, misunderstanding was evident (emphasis added):

185 Some mention should be made of the only clear example of a potential misunderstanding of the meaning of words within the written statements. In par 40 of his written statement $\mathrm{Mr} \mathrm{Y}$ said 'As the river crosses $\mathrm{X}$ country, the bed, banks, waters and resources of the river belong to the X.' I would normally have understood the word 'resources' to mean physical resources, such as fish. However, in his oral evidence $\mathrm{Mr} Y$ said that he had used the word, or at least understood it, to mean 'stories'. Given the evidence as to the spiritual and traditional significance of 'stories' the use of the word 'stories' in that context is understandable. It seems

15 T748.36-749.35. 
to me that this is an example of what is probably obvious - some care needs to be taken in ensuring that a witness's evidence is not misunderstood by reason of a difference in understanding the meaning of words. In the event this misunderstanding did not have any effect in this case. It was identified during cross examination. It also did not matter. It was clear from Mr Y's evidence that he did understand that physical resources, such as fish, within the river were 'owned' by or 'belong to' the clan over whose land the river (including the fish) was situated ...

In this comment Justice Selway is treating paragraph 40 of the witness statement 'as if' Y had actually said or written the precise words quoted. However, 'resources' is one of those quasi-legal words that had been introduced in the writing up of the statement - a word that has a precise meaning for the lawyers in the court. It had been introduced to gloss what the witness had actually said originally, as a kind of shorthand, linking the statement efficiently to a particular point of native title law. The witness had no appreciation of this. In the context of the cross examination in which the contents of paragraph 40 were raised, the witness's concern was to try and make sense of the word in that more immediate context. The context 'paragraph 40 of a long document which is based on words I once spoke but was not written by me' was basically inaccessible to him. Since the place being talked about in that exchange happened to be a major sacred site, his fixing on the abstract meaning of resource as 'spiritual resource ('stories')' was unsurprising. Discourse mediated through witness statements is full of such moments, although often this is only fully evident to the linguist sitting uncomfortably in the second row.

At the end of his cross-examination, counsel for one of the respondent parties attempted to cast doubt on the status of the witness statements by putting the 'as if' convention on the record. He questioned $\mathrm{X}$ as follows:

Counsel for the Respondent (CR): I just wanted to ask you about your affidavit: did somebody help you prepare your affidavit? Affidavit, that's your main statement; it's all your information in it. Did somebody help you prepare that?

$\mathrm{X}$ : My statement?

CR: Yes.

$\mathrm{X}$ : I mean, do - somebody was writing it, or - - -

CR: Yes

[Discussion in language between $\mathrm{X}$ and the interpreter]

$\mathrm{X}$ : Yes. There was - Howard, is it?

CR: Professor Morphy was it? ... Okay. Somebody else? Ms Hetherton, the lawyer?

$\mathrm{X}$ : Yes [more in this vein] ... 
CR: ... And so some of the words in those statements perhaps are not your words, maybe they're words that somebody else has put in? For example, that word 'right' ... That's not your word, I gather, that's more $---$

$\mathrm{X}$ : What you mean 'right'? Rights?

$\mathrm{CR}$ : Yes, there was a bit in your statement that [one of the other counsel for the respondents] was reading to you and it talked about you having a right to do something, and ... all I'm asking you is, was that part of the statement written by you, or maybe that was written by, with the help of other people?

$\mathrm{X}$ : Oh, it was my language - - -

CR: Yes.

$\mathrm{X}$ : - - because it is new to me to speak English. I have - this is my second language.

CR: Yes, and you're very good at it too, I must say. I wish I was as good at English as you are.

X: I wish I was going to speak proper English and I'm read or write - -

CR: No, you're very, very good.

$\mathrm{X}$ : - - - then I can do it myself. ${ }^{16}$

It is fair to say, bearing in mind the judge's comments in his judgment, that this ploy was unsuccessful, and his Honour appreciated X's sardonic response at the time. But it is by no means clear that the ploy ought to have been unsuccessful. In native title proceedings a great deal of time and thought has gone into the precise evidential status of expert reports - particularly anthropologist's reports. But the evidential peculiarities of the witness statement have gone largely unexamined, and while they remain so they are potentially a source of disadvantage to the witness. They expose the witness to the possibility of hostile cross examination, in which they are asked to defend or reproduce statements - said to be theirs - that are not couched in the language nor in terms of concepts that they themselves would have used. ${ }^{17}$ Moreover, in this case of 'enforced commensurability' the witnesses, in acceding to the proposition that the witness statements are their statements, are also, perforce, acceding to this particular representation of 'their' laws and customs.

\footnotetext{
16 T905.16-905.43

17 Sturt Glacken (pers. comm. 9 November 2005) points out that scrutiny of experts comes for different reasons because they must be shown to be independent, and the factual basis and methodology for their opinion must be laid bare. While acknowledging this to be true, I would say, nevertheless, that there are also good reasons to scrutinise the status of the 'facts' as they are laid out in witness statements.
} 


\section{The Yolngu response}

I now turn to a consideration of how the Yolngu witnesses viewed this arena, how they chose to act in it, and to what end. I use the word 'choice' because although the role of the witness is the most constrained of any of the actors in the court, there is still scope for alternative ways of acting in that role. It is fair to say that the Yolngu witnesses had a very precise appreciation of the ritual nature of the court and of the power relations that obtained within it. The second point on which most witnesses were pretty clear was the nature of the hierarchical relationship between customary law and native title, within the context of the court. But it is one thing to acknowledge differential power, and quite another to acquiesce to the legitimacy of the relationships so constituted, or to view them as just.

I will discuss two kinds of action that the Yolngu took within the constraints placed upon them, and their reasons for those actions. The first is the insertion of performances of rom. The second is the Yolngu commentary on difference, and insistence on difference, and on the need for rom to be seen in its own terms - the insistence on incommensurability. Through both these kinds of actions, I will argue, Yolngu were making statements about sovereignty, not simply about 'rights'.

\section{The insertion of performance: sacred power made manifest}

The Yolngu announced to the court that they wished to perform a short ceremony before the court started in order to 'welcome' the judge and the court. This wish was granted. A group of men, followed by women, all wearing white paint on their foreheads, processed into the court chanting loudly and calling out ceremonial names of country to the accompaniment of clapsticks (Fig. 2.3). They bore with them two very large public ceremonial objects representing the ceremonial walking sticks of Yirritja moiety ancestral beings associated with a place within the claim area called Gänganbuy, richly adorned with feather-string (Fig. 2.4). The choice to represent this place and its law was very deliberate. For the Yolngu clans of the Blue Mud Bay area it is the place from which the rom of the Yirritja moiety originates. 


\section{Fig. 2.3 The opening ceremony: approach to the court}

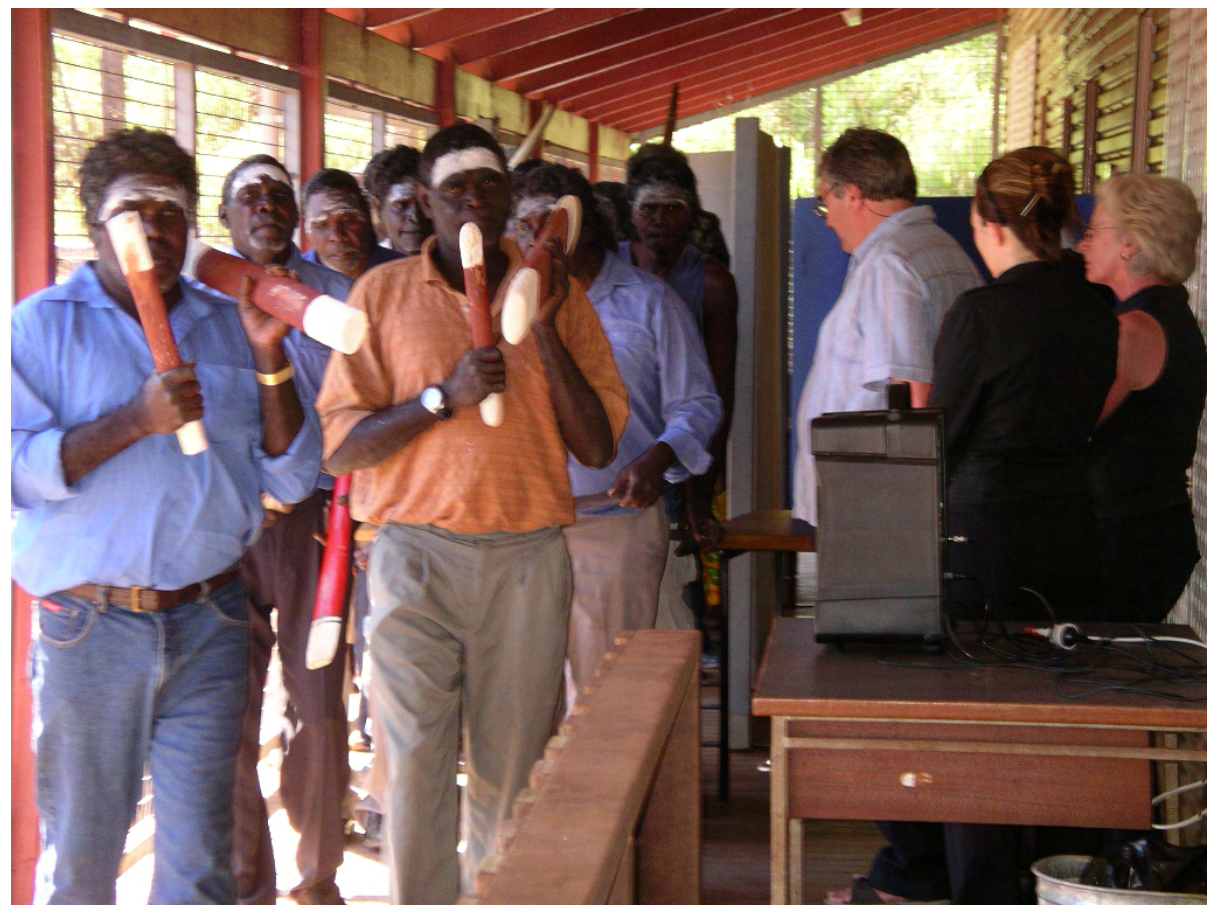

Photo: Courtesy of Sonia Brownhill

In order to accommodate the performance inside the courtroom it was necessary to disrupt the spatial ordering of the native title court by moving aside the tables and chairs facing the judge's 'bench', where the judge sat. The performance in the confined space of the court was visually and aurally extremely powerful - the lawyers and other court officials were displaced to the periphery of the arena. The judge, significantly, was not; he sat at his 'bench' throughout the performance, which ended with the ceremonial objects being laid against the bench, and the Yolngu leaving the court. The court space was reconstituted, the ceremonial objects were moved out of the courtroom, and the court then got down to its business. But for a moment, it must have seemed to the non-Yolngu present, as it certainly did to the Yolngu, that rom had momentarily displaced Australian law in its own space. 
Fig. 2.4 The opening ceremony: in the court

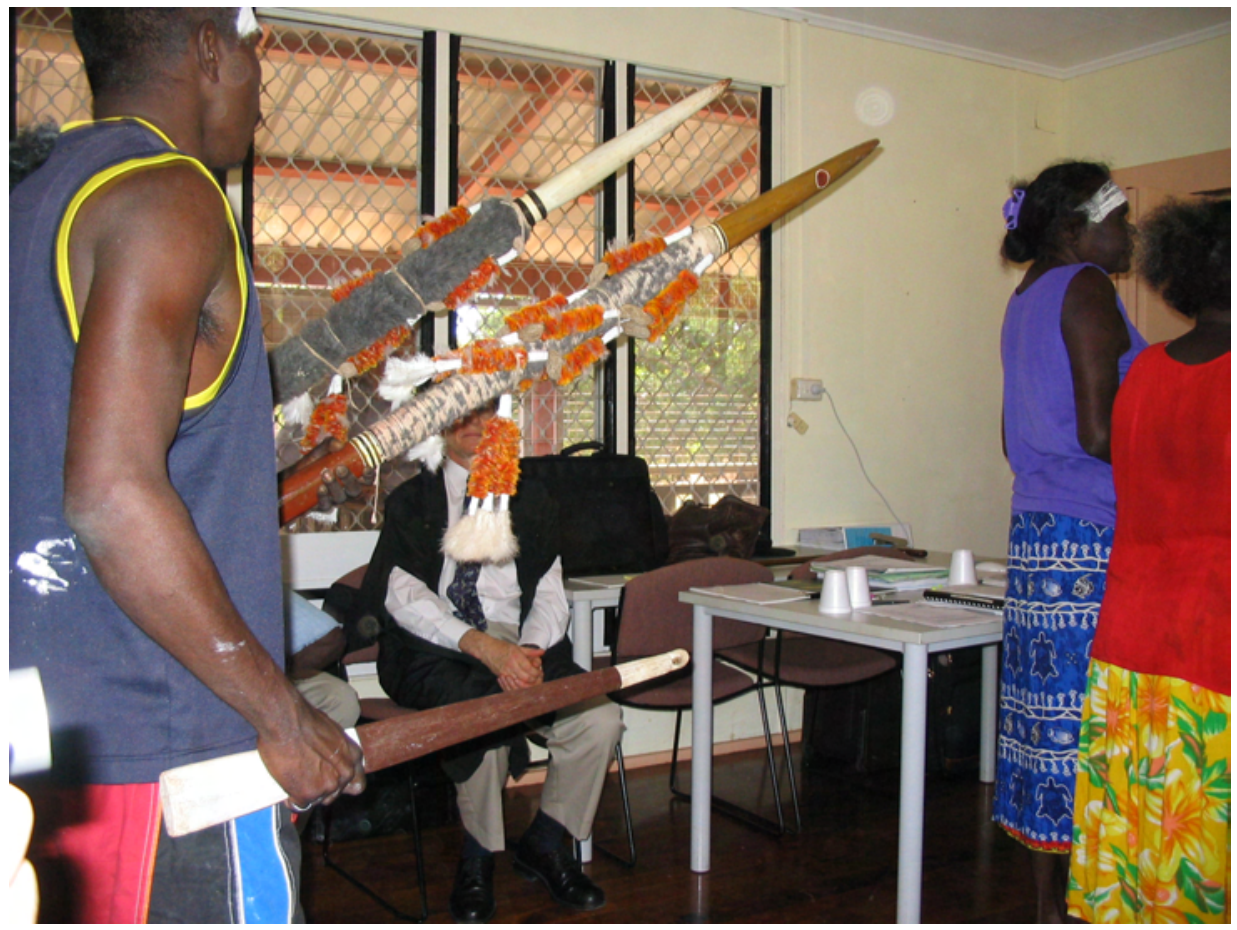

Photo: Courtesy of Sonia Brownhill

The second insertion of a performance of rom took place on the first site visit to the homeland settlement of Yilpara on Blue Mud Bay itself. The Yolngu had chosen this time very carefully, situating it near the beginning of the proceedings, and had been preparing for it for months. The male members of the court were taken to the men's ceremonial ground (Fig 2.5). Female members of the court, by consent, and including the female counsel for one of the respondent groups, were led to the edge of the ceremonial space, but then were led back (by me under instruction from the ceremonial leaders) to sit with the women in the main settlement while the men went to the restricted ground. As the men returned the women (including the non-Yolngu women) sat with their backs to them, only turning under instruction when the men were close (Fig. 2.6). This was not just a performance of rom in its own ritual space, but an enactment that incorporated the members of the Federal Court as actors, under the terms of rom. 
Fig. 2.5 The court at the edge of the Yolngu law space

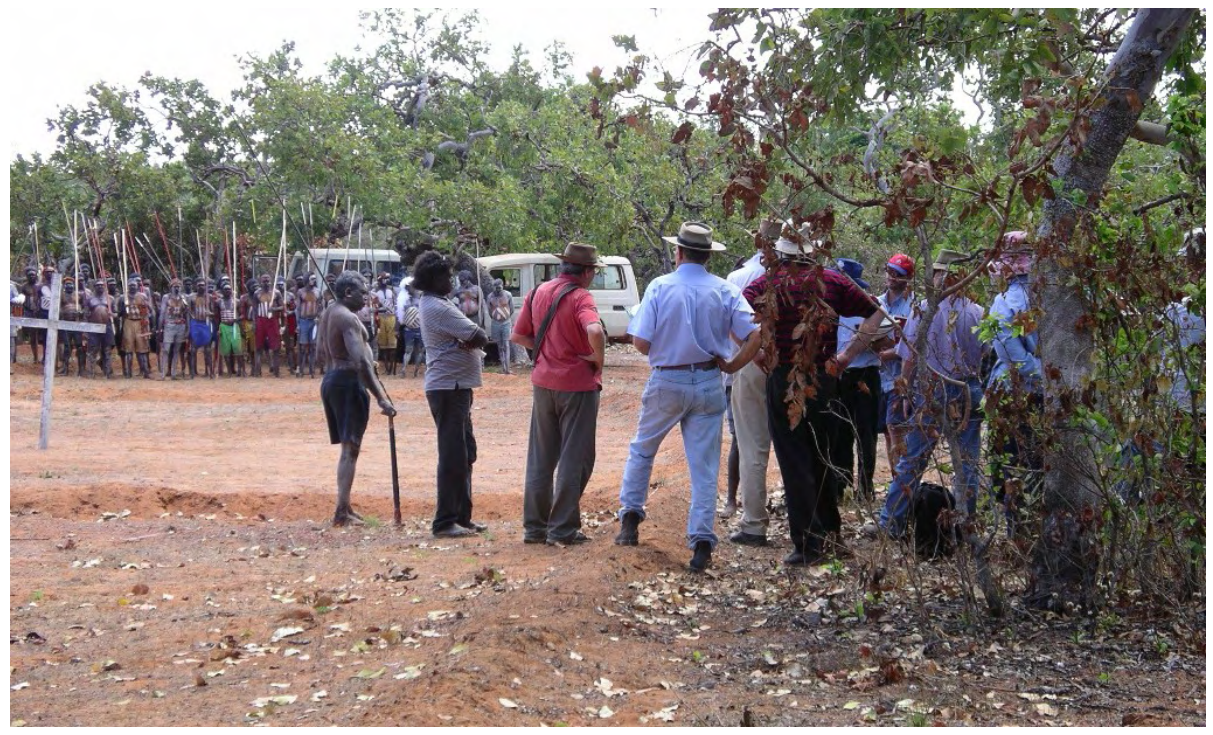

Photo: Courtesy of Daniel Lavery

Fig. 2.6 The return from the Yolngu law space

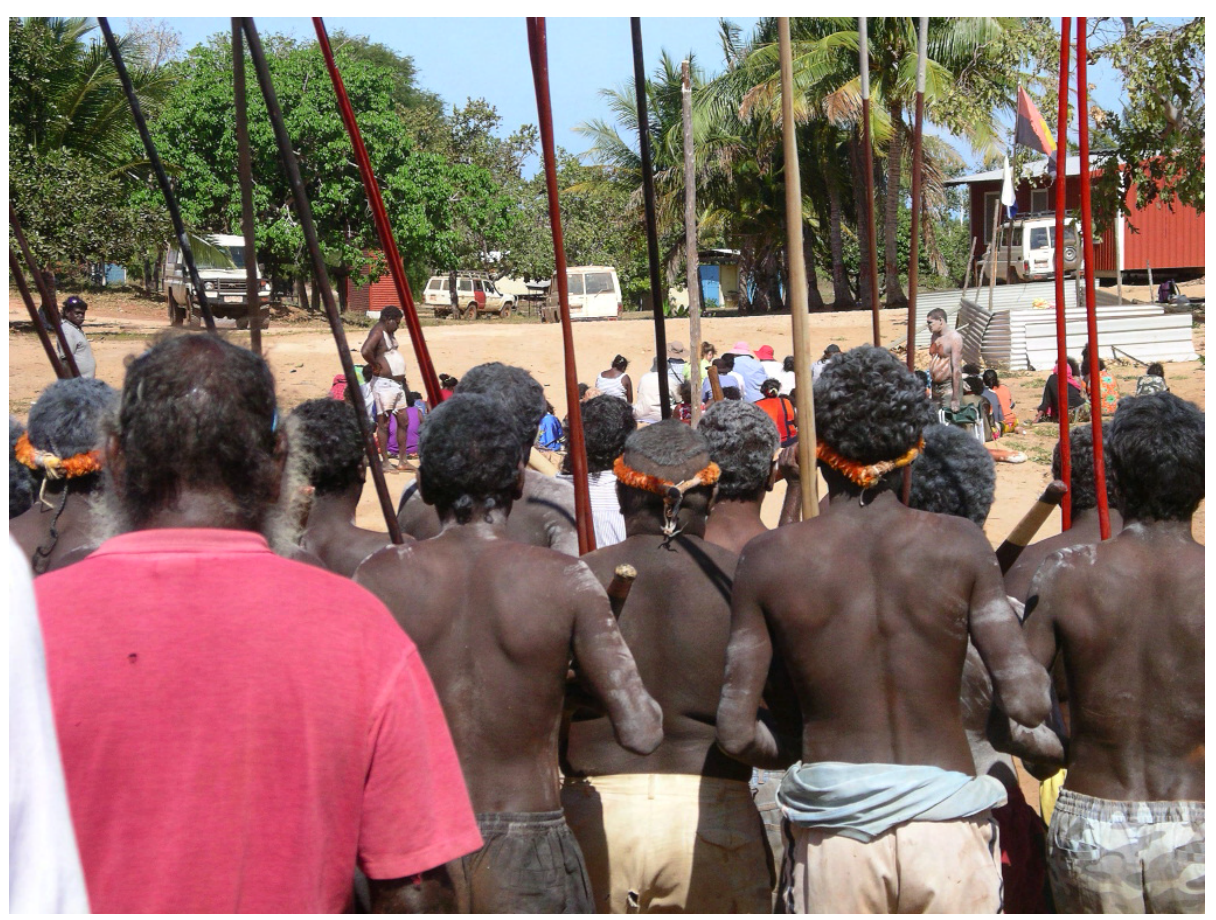

Photo: Courtesy of Daniel Lavery 


\section{The advantages of giving 'non-evidence'}

These two ritual performances could have been admitted as evidence, had the ground to do so been prepared. ${ }^{18}$ But before the welcoming performance, no-one had suggested to counsel for the applicants that it should be regarded as having evidential content. In the case of the performance on the ceremonial ground, there was an issue about procedural fairness, because the other parties had had no opportunity to ask questions, at the time of the performance, about what was happening. The judge was concerned about what an appeal court would make of the event in the absence of a transcript or other recording of it. His decision in the end was to treat it as a 'view', 'to be understood by me as a background or context to understand later evidence' ${ }^{19}$ He considered it to have been a 'wonderful experience', ${ }^{20}$ and went further when counsel for the applicants tried to persuade him that at least the explanatory statements made by one of the witnesses in the 'restricted session' could be regarded as evidence:

CA: ... I appreciate - I accept fully that my learned friends haven't any or any adequate opportunity to cross-examine, but that - - -

HH: But they didn't have any capacity to object. It was - the Federal Court of Australia was not in session. I can't see how anyone could think we were in session. It wasn't -

CA: Well, I'm in your Honour's hands.

HH: It would have been completely inappropriate, completely rude, completely out of the question for that to be the Federal Court of Australia having a session.

CA: I hear what your Honour says.

HH: It simply was not that. That's not what it was. ${ }^{21}$

Although the judge did not then elaborate as to 'what it was', the implication was clear. The men's ceremonial ground-or perhaps the nature of the performance that took place there - was not within the jurisdiction of the Federal Court. Had the Yolngu submitted these performances as evidence, this arguably would have lessened their force, because once situated within the frame of the court as 'evidence', they would have been deemed by the court to be performances but not enactments.

These Yolngu performances were deployed in a politics of persuasion, as part of their embedded discourse about sovereignty. Although not evidence, the power of these performances, in their enactment, inevitably became part of the wider context in which their evidence in court was then heard.

\footnotetext{
18 This section of the paper has benefited greatly from comments by Tom Keely (pers. comm. 3 April 2007).

19 T221.46-7.

$20 \mathrm{~T} 221.38$.

21 T222.28-43, emphasis added
} 
The Yolngu were not necessarily fully aware of the court's distinction between performance as 'evidence' and performance as 'view', nor of its legal implications. Nor was it relevant to them, in that, to borrow Nancy Williams' terminology, demonstration is in and of itself explanation, in the Yolngu view. Indeed, the informal space of the 'view' is arguably the most effective space for a discourse about sovereignty precisely because it is not subject to the adversarial discourse of cross-examination. Thus the Yolngu had achieved exactly what they had set out to do in their two ritual performances. They had estimated, correctly, that the person whose opinion really mattered was the judge's, and they had asserted that rom had its own jurisdiction, by enacting it through performance. ${ }^{22}$

What happens to the discourse about sovereignty when it becomes overt in the context of the court is demonstrated by the following passage from the court transcript - an exchange between the counsel for one of the respondent parties and witness W:

CR: ... Now, in that paragraph you say that Yolngu law applies to everyone on Yolngu country whether they are Yolngu or Aboriginals from other parts of Australia or even non-Aboriginal people; is that right? Does Yolngu law apply to non-Aboriginal people just because they're on Yolngu country?

W: Yes.

CR: So you really expect non-Aboriginal people who are on Yolngu country to follow all of Yolngu law?

W: Yes.

CR: Okay. Now, under Yolngu law people are either Dhuwa or Yirritja, is that right?

W: Yes.

CR: But non-Aboriginal people like the ones living at Nhulunbuy, they're living on Yolngu country, aren't they?

W: Yes.

CR: But they're not either Dhuwa or Yirritja, are they?

W: No. ${ }^{23}$

The same question and answer routine was then deployed to extract a 'no' answer about clan membership, initiation ceremonies, and correct behaviour with kin, and the passage ended thus:

22 It may be that the Yolngu actually wanted to achieve more through the enactment of rom-namely to force the recognition of its sovereignty in relation to Yolngu land and sea. However, although the judge was explicit in his recognition that this was a separate system of law with its own jurisdiction, he was not thereby making a statement about sovereignty. As noted before, like all the other non-Yolngu involved in the case he was working from the premise that the Australian legal system and the Australian law is, unequivocally, an expression of the sovereignty of the Australian state over all its citizens. I am grateful to Sturt Glacken (pers. comm. 9 November 2005) for comments that helped me to clarify my thinking on this point.

23 T643.04-28. 
CR: So really Yolngu law doesn't apply to non-Yolngu people, does it, just because they're on Yolngu country?

W: Yes, it does. ${ }^{24}$

It is hard to know what counsel for the respondent was trying to achieve here, apart from the undermining of the witness's confidence, to soften him up for subsequent questions. It was notable that he did not touch on those aspects of 'Yolngu law' relevant to native title - aspects relating to permission - until after this exchange. W's final response is interesting, since it seems at face value to be merely defiant, and to be unsupported by his answers to the previous questions. ${ }^{25}$ It is, however, supported by a deeper logic concerning the nature of sovereignty.

\section{Ancestral forces insert their own performance}

On the second site visit it seemed that the sea itself had decided to make manifest its ancestral forces. In the preceding days it had been like a millpond (Fig. 2.7). Indeed this time of year had been chosen for the hearings because it was usually a time when Mungurru, this named body of deep saltwater, was calm. ${ }^{26}$ But when the court arrived at Blue Mud Bay on the day appointed for the view by boat, it was anything but (Fig. 2.8). The party set off in two big boats and an aluminium dinghy, but once out in the bay, in big seas, it became clear that the view would have to be aborted. The dinghy turned back first. The judge, fortunately, was in the biggest and best protected boat, and he and the witnesses and barristers who were with him suffered only a bit of a buffeting. Those of us in the second boat, pictured in Fig. 2.8, returned somewhat battered, shivering and soaked to the skin.

\footnotetext{
24 T644.26-29.

25 It should be noted, however, that in cases where Yolngu forge friendships with non-Yolngu people those people are, invariably, incorporated into the Yolngu kinship system, and thus into a moiety and a clan. In many cases they are also given a Yolngu name.

26 For a detailed discussion of the sea country of the Yolngu and their relationship to it see Morphy and Morphy (2006).
} 
Fig. 2.7 Mungurru on a calm day

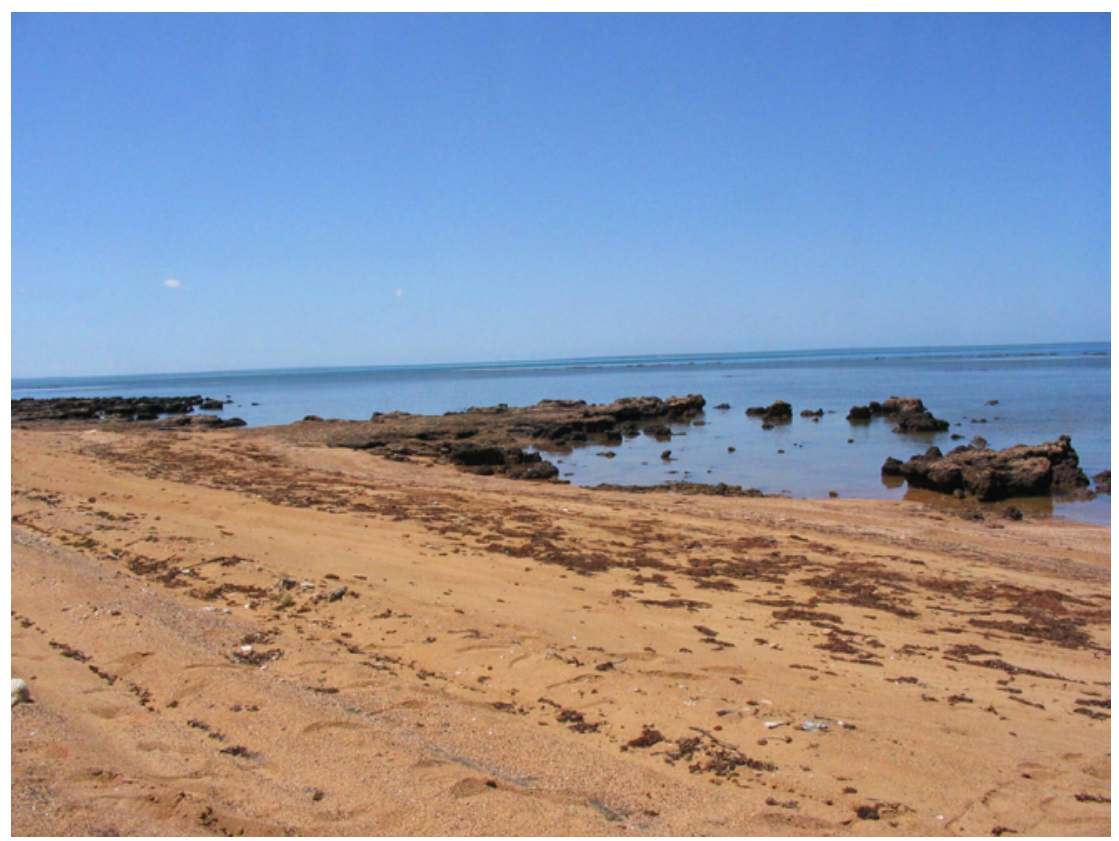

Photo: Frances Morphy

Fig. 2.8 Mungurru on the day of the 'view'

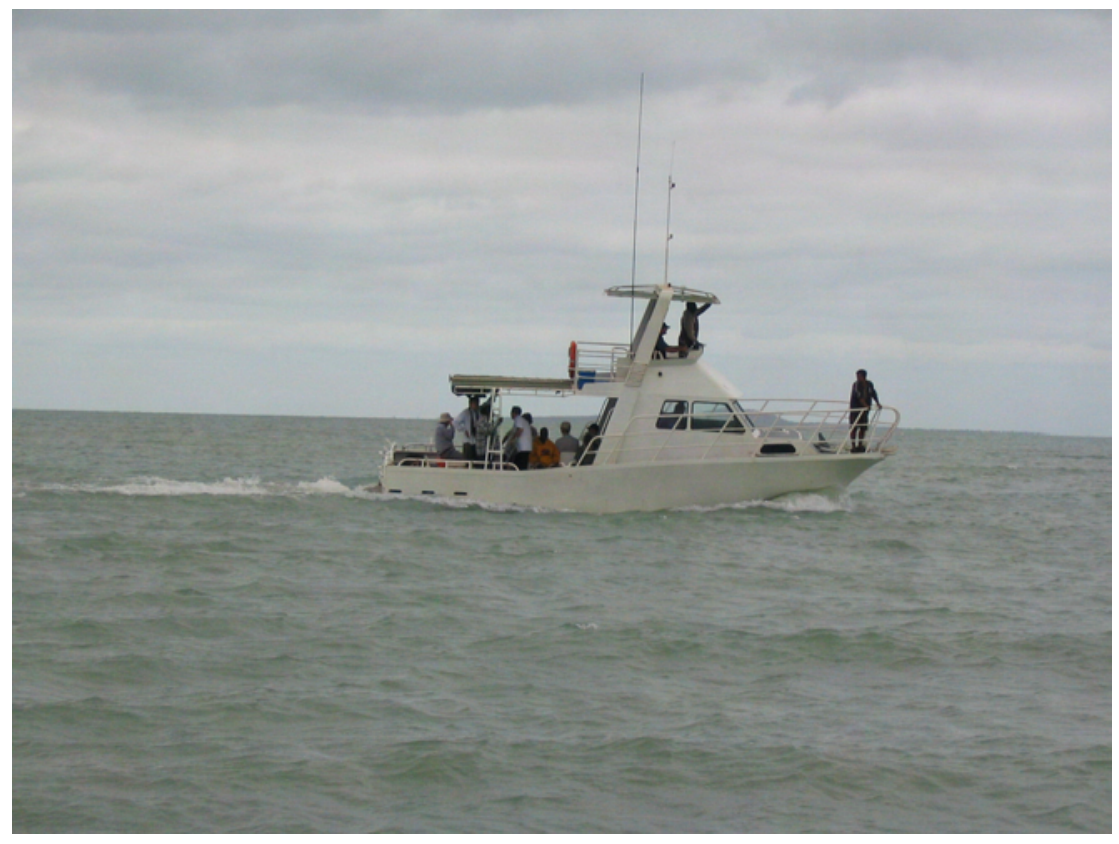

Photo: Courtesy of Daniel Lavery 
In the boat, at the height of the battering, one of the interpreters had said to me, sotto voce, 'they won't forget the name of Mungurru now.' Later on the same day I heard Yolngu saying to one another that Mungurru had been offended by the presence of so many strangers. At least some of the non-Yolngu who experienced the power of Mungurru on that day were prepared to acknowledge the believability of the belief, or at least to acknowledge the strength of the Yolngu belief. In court the next day, the following exchange took place between one of the respondents' barristers and the witness who was then in the box:

$\mathrm{CR}$ : ... Mr X, a last question from me: yesterday when we went out to sea, it was very rough; do you have a belief or an explanation as to why it was rough yesterday?

X: I felt it myself too. Yes, I felt it; maybe the country didn't want us, or the sea didn't want us.

CR: Was that that Mungurru you think?

$\mathrm{X}$ : That's the Mungurru I'm talking about.

CR: So was that the reaction you think he may have had?

$\mathrm{X}$ : Yes.

CR: Thanks very much, $\mathrm{Mr} \mathrm{X}$.

$\mathrm{X}$ : Thank you. ${ }^{27}$

The Mungurru episode and its interpretation holds the key to understanding $\mathrm{W}^{\prime}$ s final assertion in the passage quoted above, and to the Yolngu insistence on incommensurability discussed below. For the basis of rom, in the Yolngu view, is not something that they as human agents have the power to determine. It is determined - always was and always will be - by the ancestral creator beings of the Yolngu world, and such forces are not something over which humans - any humans - have sovereignty. In that sense then, Euro-Australian law can never have sovereignty over rom, no matter what mundane power relations hold, in a political sense, between the two communities.

\section{The insistence on difference}

Technically speaking, Yolngu are Australian citizens and Australian law is 'their' law as much as it is any other Australian's. But their way of modelling the relationship between the two laws shows clearly that they view the matter rather differently. As one witness put it:

We're living in the two worlds today, for example. Your world is change every day or every month or every year. My law and my story, it can't change. $^{28}$

\footnotetext{
27 T904.33-905.03.

28 T284.02-04; the witness did not mean by this that rom cannot accommodate new circumstances, but that its basic and underlying principles are eternal and immutable.
} 
It is not simply that Yolngu value their difference and assert their 'right' to be different. From their point of view it is not a matter of choice. They feel themselves to be fundamentally and intrinsically different from 'white' people because of their relationship to their country and its ancestral forces. As the same witness put it, succinctly, 'You stand for power, white people, but we stand for our land and the sea'. ${ }^{29}$

In the context of the court hearing, Yolngu constantly asserted difference. They pointed out the non-equivalence of concepts, and the problems of translation between the two systems, and in particular they asserted the permanence of rom (as opposed to 'law'). Here is just one example of several, in which a witness's evidence is being led by the counsel for the applicants. There are many things going on in this dialogue. One is an assertion of the difference between Yolngu rom and Euro-Australian 'law', but there is also, in effect, a debate about the nature of the translation process, in which Yolngu are compelled to use English terms such as 'law' when talking about their own institutions:

CA: ... you mentioned your law, or 'our law' I think you said. Well, what do you mean by that? What do you mean by your 'law'?

$\mathrm{X}$ : My law.

CA: Yes.

$\mathrm{X}$ : Well, what's that 'law' mean?

CA: That's right.

$\mathrm{X}$ : What in your - - -

CA: That's the question I'm asking you.

$\mathrm{X}$ : I'm asking too: what is 'the law' means?

CA: Well, you - - -

$\mathrm{X}$ : In balanda [English/white person's] way, what youse call it?

CA: You - you said, 'Under our law, we line the turtle shells up', as I understood you.

X: Okay, exactly - - -

CA: That's part of your law. What did you ---

$\mathrm{X}$ : Well, exactly what I'm talking now. When I'm using Balanda English, well, you should know better than me, you know, because I'm - I'm talking in Yolngu way too you know? My - my tongues are turning around, like, Yolngu way I'm talking, and if I'm using your English now, you should understand this is new to me ... my really language is Yolngu language ... And I cannot - you know, when you talk to me, you know - what is Yolngu story, what this 'law' means, you know, well, I just pick up the English, 'law'. My ngarraku rom, my ngarraku rom is different. I call it rom. ${ }^{30}$ 
CA: And what does that word mean?

$\mathrm{X}$ : Well, I'm telling you it - the law been there forever. It was given from our ancestors to our grandfathers to our father to me. This is what I call rom and law. I'm just putting that English into my - in my way of using of - using or thinking, you know, law. You call it law; I call it rom. ${ }^{31}$

This insistence on incommensurability might not necessarily have been to the applicants' advantage in the context of a native title hearing. And it is notable that $\mathrm{X}$ introduced it in a dialogue with his own counsel. He was, in effect, restating the Yolngu position as summarised in the introduction. Yolngu rom has been encapsulated by ngapaki law, but it has not been colonised by it. It cannot be-it remains distinct, it is everlasting, and it is incommensurable with ngapaki law. In this witness's view, stated in another context, so long as Yolngu hold fast to their own rom they will be Yolngu. If they abandon rom, the rom will remain in the country, but Yolngu will no longer be Yolngu - they will just be 'Aborigines'. Yolngu identity is thus deeply bound to the fundamental underlying principles of governance generated by rom. It is, as they say, the 'foundation' of their existence and identity. Native title as a process seeks to impose commensurability between rom and law in order to make the former legible to the latter, and so potentially 'recognisable'.

Yolngu thus find themselves in a complex double bind. To submit rom to commensurability is in itself impossible in the Yolngu view, whatever the pretensions of the ngapaki native title law. To submit their own conceptualisation of rom to a process of enforced commensurability risks alienation from rom, and from their identity as Yolngu. Yet in resisting commensurability they potentially deny themselves advantages that might accrue from recognition of 'their' native title. Their response to this double bind - seeking to maintain a discourse about sovereignty within the dominant discourse of native title - was equally complex.

\section{Conclusion}

At the time of writing, the Blue Mud Bay case is still in the court system. It is a complex case involving both native title and the ALRA - the latter with respect to the waters above the intertidal zone, which is Aboriginal land under ALRA. Both matters were run simultaneously, under native title conditions, that is, as a hearing before a Judge of the Federal Court. The determination (as finalised by Justice Mansfield following the untimely death of Justice Selway) found that Yolngu have exclusive native title to their land country, and while Justice Selway felt himself bound by the Yarmirr decision in the High Court to say that exclusive native title rights and land rights under the ALRA do not extend to the waters

31 T127.45-128.05. 
over the intertidal zone, this does not, in his opinion, reflect the situation under customary law which is no different to that on the land proper:

The Northern Territory also submitted that the evidence did not establish a right to exclusive occupation of the sea. In this regard the Northern Territory referred me to the factual findings of Olney $\mathrm{J}$ in Yarmirr TJ. In that case his Honour was not satisfied that the relevant Aboriginal tradition involved a right of exclusive possession. I can only assume that his Honour was faced with different evidence to that which is before me (Selway J 2005 [214]). ${ }^{32}$

This initial finding can be seen as a partial victory - the most that could realistically be expected under the native title regime. It states, in effect, that prior to colonisation rom was sovereign both on the land and in the sea. But the Yolngu did not see this as a victory, and nor indeed was it, in terms of Realpolitik, since it did not give them the control that they were seeking over their sea country. For his part, Mr Justice Selway regarded his conclusions as problematic for reasons to do with the relative status of various kinds of European law, particularly the status of the common law 'right to fish' as against the status of fee simple under the ALRA, thus giving possible grounds for appeal. In the appeal to the Federal Court, three Federal Court Judges overturned the part of his determination relating to the operation of the ALRA in the intertidal zone, so that the waters over the intertidal zone now come under the ALRA (at least for the moment), and Yolngu (and all other traditional owners with coastal estates on ALRA land) have the right to exclude others from their intertidal waters. The case will now go to the High Court.

In the 'recognition space' of the native title arena the Yolngu, despite convincing the Judge that under their customary law they had the right to exclude others from their sea country, failed to get that exclusive right recognised in Australian law. Their interim victory on first appeal relies on the ALRA rather than native title, so has no implications for others outside the ALRA lands. From the perspective of the applicants if not from those raised to view the rules of Euro-Australian legal procedure as normative, irony has now taken centre stage. The only protagonists in the appeals process are judges and other lawyers - practitioners of Australian law. If Yolngu attend it is only as the

\footnotetext{
32 Nicholas Evans, in a paper on the linguistic evidence in the Croker (Yarmirr) case, points out that 'much of the evidence that led Justice Olney to this conclusion [that the permission system applied only to Aboriginal people] turns on modal verbs [e.g. 'can', 'must', 'should] in the witness' evidence' (2002: 87). He goes on to show that Justice Olney misinterpreted a key witness's non-standard use of modal verbs, deriving a meaning from the witness's statement that was precisely the opposite of what the witness had intended by his evidence. There is a strong case for saying, then, that Justice Olney did not in fact hear evidence that was substantially different from that heard in the Blue Mud Bay case, but rather that the judgement in the Yarmirr case was based on flawed analysis of the evidence, with potential repercussions down the line for the Blue Mud Bay case and, indeed, all subsequent native title cases that concern the sea.
} 
public', although it is the fate of their sea country and of their relationship to it that is in the balance.

The Yolngu experience of the native title process has thus far been relatively benign, certainly by comparison with the experiences of some other claimant groups detailed in this volume (see e.g. Redmond, Chapter 4). They started from a position of strength. They already held their land country under ALRA, and they had never been alienated from or forced off their land estates, so that many of the issues about identity that other claimant groups face did not arise. As a collectivity they were able to show a united front, and to put forward a coherent, consistent and convincing account of their system of 'laws and customs'. There were no competing claims. They brought to the arena a strong view of themselves as uncolonised subjects. The fact that part of the case related to ALRA rather than to native title was also an advantage, since there was the prospect of gaining delimited exclusive rights under that regime, whereas, because of Yarmirr, there was really no prospect of gaining exclusive native title rights to the sea. They also encountered a judge with whom they were able to forge a relationship of mutual respect, even if neither party fully understood the other's agenda. Justice Selway's clear insistence on the limits of his interests in the case, legally speaking, combined with his evident respect for their system of 'laws and customs', provided a space for Yolngu to reaffirm their sense of sovereignty - at least to themselves, and for the time being.

The Yolngu of Blue Mud Bay have not as yet been exposed to the full weight of codification, as described by Glaskin in this volume (Chapter 3), since there has been no move, as yet, to set up a prescribed body corporate for the claim area. For the moment, through resisting commensurability in the court, they have been able also to cleave to the 'two worlds' model, in which the state's particular objectification of 'their' native title is seen by them as essentially irrelevant to rom and the social field that is founded in it.

However, in the court's terms the dialogue could be perceived at most as being about jurisdiction, and 'rights'. In the longer term the Yolngu view of themselves as encapsulated but not colonised - as 'living in two worlds' — will come under increasing pressure. They have been able to sustain that view until now because ALRA, unlike most European law, appeared immutable. In reality, like any other piece of Euro-Australian law, it can be changed and its effects substantially undermined by a government with the will to do so operating in particular political circumstances. Those changes - which may be viewed as the final act of colonisation - are beginning to happen now.

\section{Acknowledgments}

I thank the participants in the 'Effects of Native Title' workshop for their comments on the version of this paper that was presented there, and Sturt 
Glacken for his thoughtful and perspicacious comments on the first draft of the paper, and for saving me from solecisms that were the product of my unfamiliarity with matters of the law. I would like to have addressed all his comments, but that would have turned this into a different - and longer - paper. The second draft benefited greatly from Tom Keely's detailed comments, and I hope that I have gone some way towards taking them properly into account. I also thank Daniel Lavery, David Martin, Howard Morphy and Rebecca Morphy for their comments on the second draft. Needless to say, all remaining solecisms and errors of fact or interpretation are my responsibility alone.

\section{References}

Evans, N. 2002. 'Country and the word: linguistic evidence in the Croker sea claim', in J. Henderson and D. Nash (eds), Language in Native Title, Native Title Research Series, Aboriginal Studies Press, Canberra.

Gawirrin Gumana \& Ors vs Northern Territory of Australia \& Ors 2004. Federal Court Transcript.

Mantziaris, C. and Martin, D. 2000. Native Title Corporations: A Legal and Anthropological Analysis, The Federation Press, Sydney, in co-operation with National Native Title Tribunal, Perth.

Morphy, H. 1983. "Now you understand": an analysis of the way Yolngu have used sacred knowledge to retain their autonomy, in N. Peterson and M. Langton (eds), Aborigines, Land and Land Rights, Australian Institute of Aboriginal Studies Press, Canberra.

Morphy, H. and Morphy, F. 2006. 'Tasting the waters: discriminating identities in the waters of Blue Mud Bay', Journal of Material Culture, 11 (1/2): 67-85.

Selway, J 2005. The 'Blue Mud Decision' Gumana v Northern Territory of Australia [2005] FCA 50.

Stanner, W. E. H. 1979. 'The Yirrkala case: dress-rehearsal', in W. E. H. Stanner, White Man Got No Dreaming: Essays by W. E. H. Stanner, Australian National University Press, Canberra.

Williams, N. 1986. The Yolngu and Their Land: A System of Land Tenure and the Fight for Its Recognition, Australian Institue of Aboriginal Studies, Canberra.

Williams, N. 1987. Two Laws: Managing Disputes in a Contemporary Aboriginal Community, Australian Institute of Aboriginal Studies, Canberra. 